the one-inch but, as there are nearly $52,0001 / 2,500$ maps and only about 300 one-inch maps, Brigadier MacLeod thinks that the former should be regarded as the basic scale for grid purposes.

From a discussion of the various possible units, it is concluded that the choice lies between the yard and the metre. On the $1 / 2,500$ scale, the 100 metre grid square is $4 \mathrm{~cm}$. - a little on the small side though moderately suitable. The 100 yard square is 10 per cent smaller and therefore 10 per cent less suitable. An objection to the yard is that its decimal multiples ( 1,000 and 10,000 yards) are not named.

The metre has therefore intrinsic advantages over the yard, but the decisive consideration is the question of permanence. So long as there is any possibility of metric measures being adopted in Great Britain, a metre grid is preferable to a yard grid-for once the grid is introduced a change in grid unit would not be practicable. The introduction of metric measures has often been attempted, but has always failed, though sometimes only by narrow margins. Some industries already use metric units, and others will probably have to follow. Everyone is agreed that the metric system has advantages over our native systems; the difficulty of introducing it is the obstacle. Anything which will help to overcome this difficulty should be encouraged. Brigadier MacLeod believes that a metre grid would do this without causing inconvenience; it would not compel anyone to alter present survey practice or to alter units of area now in use.

As to the unit of height, if a metre grid is adopted, it might be desirable to adopt the metro for heights also. This is not essential, but would be especially desirable if it is decided to contour the six-inch map at a closer interval than the present 100 feet.
With regard to map scales, if a grid system is adopted, there are great advantages in having map scales exact multiples of one another. If the $1 / 2,500$ scale is taken as basic-a $1 / 10,000$ or $1 / 12,500$ would be preferable to a scale of six-inches to one mile. Similarly, 1/250,000 would be more suitable than four miles to one inch $(1 / 253,440)$.

The present would be a favourable opportunity for making any such changes, as the one-inch map is now being redrawn--less than one-fifth has been completed-while the other small-scale maps would in any event have to be redrawn before long.

In the discussion which followed the reading of the paper, most of the speakers confined their remarks to comments on the difficulty of getting the British public to use metric units. Few of them kept strictly to the point at issue, which was not the adoption of the metric system by the public, but the adoption of metric units for the proposed grid-not yet in existence. The substitution of 'decimal' map scales for the present scales of inches to a mile was criticised on the same grounds, but this has nothing to do with metric units being equally desirable whether yards, metres, or miles are adopted for the grid.

Prof. C. B. Fawcett, who spoke last, said that the use of metric measures is now taught in all secondary schools, and suggested that the difficulties of getting the public to use metric measures might not be as great as some people suppose.

Brigadier MacLeod concluded the discussion by reminding the audience of the merits of the metric system. Care should in any event be taken to do nothing to make its adoption more difficult. The adoption of the metre for the grid would cause no inconvenience, nor would it compel the public to adopt metric units for purposes unconnected with the grid.

\title{
Hudson Strait Survey
}

$\mathrm{T}$ HE sixty-eighth annual report of the Canadian Department of Marine for the fiscal year 1934-35 contains some interesting information respecting the charting operations which have been continued in Hudson Strait along the south-eastern coast of Baffin Island for a distance of seventy-five miles eastwards of Pritzler Harbour. The following is a description of the coast from Pritzler Harbour to Gabriel Strait.

The Lower Savage Islands, which are separated from Baffin Island by four miles of turbulent water, is a distinct group of three main and several smaller islands characterised by the same rugged topography as south-eastern Baffin Island and Resolution Island. Bare, rocky hills in great disorder rise to a height of $720 \mathrm{ft}$. above the sea. Due to the exceptionally exposed position, the islands are almost destitute of vegetation even in the declivities, and present a most desolate and chaotic appearance. With the exception of the low south-western end of the group, the islands possess a formidable sea-face, composed of a succession of lofty cliffs rising sheer out of the water. The strong tidal streams of Gabriel Strait striking heavily against the Savage Islands are sheered abruptly from their course and the accelerated swirling currents cause a confused sea with whirlpools and remarkable tide-rips. Even on fairly calm days, there occur areas of sharp uprisings of the sea, like a great boiling-up. In Gabriel Strait there was observed a most unusual difference between the spring and neap ranges of tide. This variation was found to be $28 \cdot 80 \mathrm{ft}$. at springs and only $10 \mathrm{ft}$. at neaps.

An imposing promontory, East Bluff, stands at the south-eastern extremity of Baffin Island. It is the southern termination of a great high wall of solid rock extending for $3 \frac{1}{2}$ miles along Gabriel Strait. Severe in aspect, it rises precipitously out of very deep water to a height of several hundred feet. From this great headland the ragged coast of Meta Incognita trends abruptly to the north and to the west. The shore is piereed by many small incursions of the sea and is fringed by many skerries. Outside these rocky islets, the water is deep and apparently freo from obstructions. In Gabriel Strait, the echo-sounding instrument recorded the great depth of 234 fathoms only $1 \frac{1}{4}$ miles off the land. The Grinnel glacier, which overlies most of the peninsula, approaches to within six miles of Hudson Strait and nowhere does it dis. charge any icebergs. The bare strip of country between the edge of the glacial ice cap and the sea is very hilly and deeply scored by glacial action. In summer, the melting glacier gives rise to numerous swift rivulets ; they abound in sea-trout, upon which the natives are much dependent for food. 